\title{
Cold-induced changes in cell wall stability determine the resistance of winter triticale to fungal pathogen Microdochium nivale
}

\author{
Magdalena Szechyńska-Hebda ${ }^{1,2} \cdot$ Marek Hebda $^{3} \cdot$ Magdalena Mirek $^{1} \cdot$ \\ Krzysztof Miernik ${ }^{3}$
}

Received: 10 November 2015/Accepted: 11 May 2016/Published online: 17 June 2016

(c) The Author(s) 2016. This article is published with open access at Springerlink.com

\begin{abstract}
The exposure of winter triticale to cold promotes genotype-dependent resistance to fungal pathogen. We present the evidence that structural and chemical modifications of the cell wall components induced by cold can be correlated with the resistance against fungal infection. Our results showed that cellulose of hardened triticale cv. Hewo (able to develop resistance after cold treatment) has more compact and integrated structure, thicker and longer fibres when compared to cv. Magnat (susceptible to fungal infection despite plant hardening). Such structure of cellulose limits water sorption, favours stronger bonding the water of crystallisation to macromolecules, impedes depolymerisation process during decomposition, and finally results in higher thermal stability of cell wall. Furthermore, the lignin composition is drastically modified in resistant plants. Pattern of the thermal decomposition indicates higher molecular mass and more complex structure of lignin, followed by the higher thermal stability. We conclude that specific structure of lignocellulosic cell wall of the resistant plants forms a barrier for fungal enzymes digesting host tissue as well as can resist better the mechanical pressure of hyphae.
\end{abstract}

Magdalena Szechyńska-Hebda

szechynska@wp.pl

1 Institute of Plant Physiology, Polish Academy of Sciences, Niezapominajek 21, 30-239 Krakow, Poland

2 Department of Plant Genetics, Breeding and Biotechnology, Warsaw University of Life Sciences, Nowoursynowska 159, 02-776 Warsaw, Poland

3 Institute of Materials Engineering, Cracow University of Technology, Warszawska 24, 31-155 Krakow, Poland
Keywords Cellulose · Cell wall $\cdot$ Lignin · TG/DSC/QMS · Pathogen

\section{Introduction}

The plant cell wall is the place where pathogen and plant initiate their interaction. For successful colonisation, pathogens must gain access to the cellular nutrients breaking of the plant cell wall with enzymes and/or with high turgor pressure created inside the invasion structures [1]. Conversely, plant responds to fungal invasion by remodelling and reinforcing the cell wall [2, 3], by inhibiting fungal enzymes that can degrade the host cell wall and by killing pathogens via antimicrobial means [4].

Plant cell wall has a heterogeneous hierarchical structure. It is built mainly by unbranched and unsubstituted cellulose microfibrils consisting thousands of $(1,4)-\beta$-Dglucose monomers. Cellulose framework is embedded in a cross-linking polymer matrix formed by pectin, heteropolysaccharide predominantly containing galacturonic acid residues; and hemicellulose, amorphous branched polymer containing glucose, mannose or xylose residues. The cell wall structure and ratio of its individual components directly influence the cell wall porosity, density and microfibril spacing, cell wall permeability and its strength, and all of them are important factors determining effect of infection. In addition, lignin, a hydrophobic polymer, provides the cell wall structural rigidity, waterproof structure and mechanical resistance $[5,6]$.

The specific composition of the cell wall depends on plant species, tissue type, developmental stage and environmental conditions during plant growth. The proportion of cellulose, lignin and other polysaccharides may change, when the suboptimal temperature, limited water 
availability and light modulation affect plant growth and development $[2,7,8]$. Therefore, abiotic and biotic stresses are often physiologically interrelated and can induce similar responses at the level of cell wall. Moreover, it was recently revealed that local and systemic acquired resistance to pathogens could be regulated by the same genetic system as the systemic acquired acclimation to abiotic stress $[9,10]$ and that a set of genes participating in metabolism of cell wall polymers is involved in the plant defence responses $[3,11,12]$. A hardening of winter crops during autumn is a factor inducing the genotype-dependent resistance to infection $[2,10]$. It was found that cold leads to accumulation of the hydrophobic substances in plant cell wall and adjustment of the physical and chemical properties of leaf surface. Moreover, submicron- and micronscale roughness of epidermis caused surface superhydrophobicity [2]. All of these alterations reduce the surface moisture (usually needed for fungus growth), limit adhesion of fungal mycelium and restrict direct penetration of hyphae through the internal tissue [2].

Both, our earlier studies and the work of others $[2,7,13-15]$, have led to the hypothesis that spatially controlled heterogeneity in the chain length and configuration of cellulose and lignin can influence the biochemical and mechanical resistance of the cell wall. Therefore, purpose of the present study was to clarify the role of the cell wall components and their stability in the cold-induced resistance of triticale seedlings to the fungal pathogen Microdochium nivale. Through scanning electron microscopy, simultaneous differential scanning calorimetry and thermogravimetry, combined with quadruple mass spectrometry, the stability of cellulose and lignin that were extracted from resistant (able to develop resistance after cold treatment) and sensitive (susceptible to fungal infection despite plant hardening) cultivars was investigated. The study showed that resistance of the plant cell wall could be determined by thermal analysis, as its individual components had different degradation profiles depended on the genotype and cold treatment.

\section{Experimental}

\section{Pant materials and treatments}

Previously selected cultivars of hexaploid winter triticale (Triticosecale Wittm.), namely Hewo (able to develop resistance after cold treatment) and Magnat (susceptible to fungal infection despite plant hardening), were used for the experiments [2]. Seedlings were grown 8 days in a climatic chamber at $20^{\circ} \mathrm{C}$, and then the plants were subjected to hardening at $4{ }^{\circ} \mathrm{C}$ for 28 days. Unhardened plants were grown at $20^{\circ} \mathrm{C}$ until they acquired the same developmental stage as the cold-hardened plants. Hardened and unhardened leaves were collected for cellulose and lignin extraction.

The monosporal isolate of Microdochium nivale with a high virulence (No. 38z/5a/01) was cultured in in vitro conditions, and the leaf infection test was performed as described earlier [2]. Each infected seedling was covered with wet blotting paper and incubated in darkness at $4{ }^{\circ} \mathrm{C}$. Ten days after infection, 20 leaves for each temperature treatment and each cultivar were collected for microscopic analysis.

\section{Cell wall components extraction}

Samples were cut with a scalpel blade to approx. $1 \mathrm{~mm}^{2}$ pieces and boiled for $30 \mathrm{~min}$ in equal amounts of water $(\mathrm{w} /$ w) to remove most of the extractives. They were rinsed on 80-mesh sieves with distilled water for removal of the starch and water-soluble compounds, and then with a mixture of chloroform/methanol $(2: 1, \mathrm{v} / \mathrm{v})$ to remove the lipids. Cleared plant material was oven-dried $\left(80^{\circ} \mathrm{C}\right)$.

The cellulose extraction was performed with acetylacetone/1,4-dioxane/hydrochloric acid (12/4/3, v/v/v). The samples were shaken for $1 \mathrm{~h}$ in a water bath at $90{ }^{\circ} \mathrm{C}$ and rinsed with $40 \mathrm{~mL}$ of methanol, $40 \mathrm{~mL}$ of 1,4-dioxane, $40 \mathrm{~mL}$ hot water and $40 \mathrm{~mL}$ diethyl ether. The cellulose was dried for $6 \mathrm{~h}$ at $100{ }^{\circ} \mathrm{C}$. The absence of lignin in extracted cellulose samples was confirmed by phloroglucinol staining ( $2 \%, \mathrm{w} / \mathrm{v}$ phloroglucinol in $95 \%$ ethanol) [16]. The average polymerisation degree of the cellulose was estimated viscometrically using $1 \mathrm{~mol} \mathrm{~L}^{-1}$ cupriethylenediamine solvent at $25.0{ }^{\circ} \mathrm{C}$ according to Ref. [17].

The extraction of lignin was conducted using Klason method [16] with modification. The samples were incubated with $15 \mathrm{~mL}$ of $72 \%$ sulphuric acid at $20{ }^{\circ} \mathrm{C}$ for $2 \mathrm{~h}$. Then, $560 \mathrm{~mL}$ water was added and the solution was boiled for $4 \mathrm{~h}$. The precipitate was rinsed with hot water and dried for $6 \mathrm{~h}$ at $100{ }^{\circ} \mathrm{C}$.

The cellulose and lignin samples were stored in sealed Eppendorf tubes in a desiccator filled with silica gel to prevent absorption of moisture.

\section{Scanning electron microscopy}

The leaf samples were fixed overnight at $4{ }^{\circ} \mathrm{C}$ with primary fixative containing: $2 \%$ glutaraldehyde, $2 \%$ paraformaldehyde, $0.13 \mathrm{M}$ sucrose, and $0.01 \mathrm{M}$ 2-Mercaptoethanol in $0.1 \mathrm{M}$ cacodylate buffer ( $\mathrm{pH}$ 7.4). They were washed four times (30 min each) in $0.1 \mathrm{M}$ cacodylate buffer. Secondary fixation was performed in $2 \%$ osmium tetroxide in $0.1 \mathrm{M}$ cacodylate buffer ( $\mathrm{pH}$ 7.4). The samples were washed three times in distilled water and dehydrated in a graded ethanol series: $25 \%(\mathrm{v} / \mathrm{v}), 50,70$, and $95 \%$, 
30 min each; and next three times in $100 \%$ for $30 \mathrm{~min}$, $45 \mathrm{~min}$ and $1 \mathrm{~h}$. The samples were the critical-point dried, coated with $15 \mathrm{~nm}$ of gold (Cressington 108 Auto sputter coater), and observed with a JEOL JSM-5510LV microscope operating at $20 \mathrm{kV}$. Cellulose samples were treated according to a similar protocol starting from a dehydration point in a graded ethanol series.

\section{Thermal analysis-Mass spectrometry}

The stability of the individual cell wall components was studied by simultaneous differential scanning calorimetry (DSC) and thermogravimetry (TG) combined with quadruple mass spectrometry (QMS) (Netzsch STA409 $\mathrm{CD})$. The DSC furnace was calibrated using melting temperatures of indium, tin, lead and zinc. The QMS was checked using calcium oxalate monohydrate (Fluka) $[18,19]$. For measurements, $20 \mathrm{mg}$ of the dry sample was put into sealed aluminium pans with lids and heated at $5{ }^{\circ} \mathrm{C}$ $\min ^{-1}$, from room temperature, to $550{ }^{\circ} \mathrm{C}$. Curves were recorded against an empty pan placed in a reference vessel. The final curve of the sample was obtained after the baseline was subtracted. The QMS spectrometer was operated in MID (multiple ion detection) mode. Control peaks corresponding to degradation of individual cell wall components were determined against the standards (SigmaAldrich): cellulose medium fibres (C6288) and lignin (471003). Each experiment was performed for three biological repeats and two technical replicates. The obtained results were evaluated by means of Proteus (ver. 5.2.0) software (Netzsch).

\section{Results and discussion}

\section{Plant hardening inhibits the growth of $M$. nivale}

In natural conditions, $M$. nivale is a psychrophilic pathogen that invades winter cereals under the snow or during wet weather and causes degradation of the cell walls and cell interior (Fig. 1) [2, 20]. On the other hand, proper plant hardening during autumn or cold treatment in laboratory conditions can promote an efficient defence mechanism against fungal infection $[2,10]$. Current (Fig. 1) and earlier results [2] reveal that a cold period of 28 days is sufficient to induce resistance to M. nivale for the cultivar Hewo, but not for cultivar Magnat. Therefore, these two genotypes can be a model for study of the cold-induced resistance. Unhardened (Fig. 1a) and hardened (Fig. 1b) winter triticale cv. Hewo was incubated with fungal pathogen $M$. nivale in conditions that mimic wet winter. Unhardened tissues were very susceptible to infection; hyphae easily grew on the leaf surfaces and formed dense mycelium
(Fig. 1a). The fungus spread even through the internal tissues, i.e. mesophyll cells. Although, the epidermis of a hardened leaf was also covered by mycelium (Fig. 1b), total number of hyphae was drastically reduced in comparison with the unhardened leaf (Fig. 1a).

\section{Cold-induced changes in cellulose}

Since cellulose is a basic cell wall component and determines the structural, physical and mechanical properties of cells, we extracted cellulosic material from the leaf fragments without mechanical grinding of tissues, to preserve organisation of the cell walls. SEM analysis of the cellulose demonstrated its slightly different spatial organisation between unhardened leaf and hardened one. Surface of the unhardened leaf was more irregular and degraded (Fig. 1c), when compared to the surface of the hardened leaf (Fig. 1d). Moreover, unhardened cellulosic fibres were relatively thinner, rough and oriented in different directions (Fig. 1c, e) making structure porous. In contrast, compact structure of hardened cellulose suggests its higher resistance to chemical and thermal degradation during process of cellulose isolation (Fig. 1d, f). Furthermore, SEM analysis of the interior of unhardened leaf showed also perforation in vascular tissues. The fibres positioned parallel to their longitudinal axis were separated and clearly seen (Fig. 1g). The average diameter of these fibres was about $0.95 \mu \mathrm{m}$ ( $\mathrm{SD}=0.24 ; n=50$ cells). The cellulose fibres oriented transversally had diameter about 0.09-0. $15 \mu \mathrm{m}(\mathrm{SD}=0.04 ; n=50$ cells $)$. Within the hardened leaf, the same regions of the vascular tissues appeared to contain much more cellulosic material. Although, the structure of internal surface was rough and parallel organisation of the cellulose fibrils was evident, the structure was compact without any perforation (Fig. 1h).

A divergence in the stability of cell wall components induced by cold can also be related to the different effectiveness of resistance induction within cultivars. To verify this hypothesis, we compared the structure of cellulose extracted from hardened Hewo (able to develop resistance) with cellulose extracted from hardened Magnat (susceptible to fungal infection despite cold treatment) [2]. Structure of hardened Magnat's vascular tissues (Fig. 2a) appeared to be similar to the unhardened Hewo tissue (Fig. 1g), rather than to the hardened Hewo tissue (Fig. 1h, Fig. 2b). Moreover, the thickness of the Magnat cell walls was significantly reduced $(698 \pm 139 \mathrm{~nm}$ for Magnat; $967 \pm 158 \mathrm{~nm}$ for Hewo; $n=50$ cells, $P=0.000325$ according to Student's t test).

The limited perforation and well-ordered microfibrils orientation in the primary cell walls of hardened Hewo can result in both, the enhanced resistance of cell wall to the mechanical forces of hyphae and the decrease in 

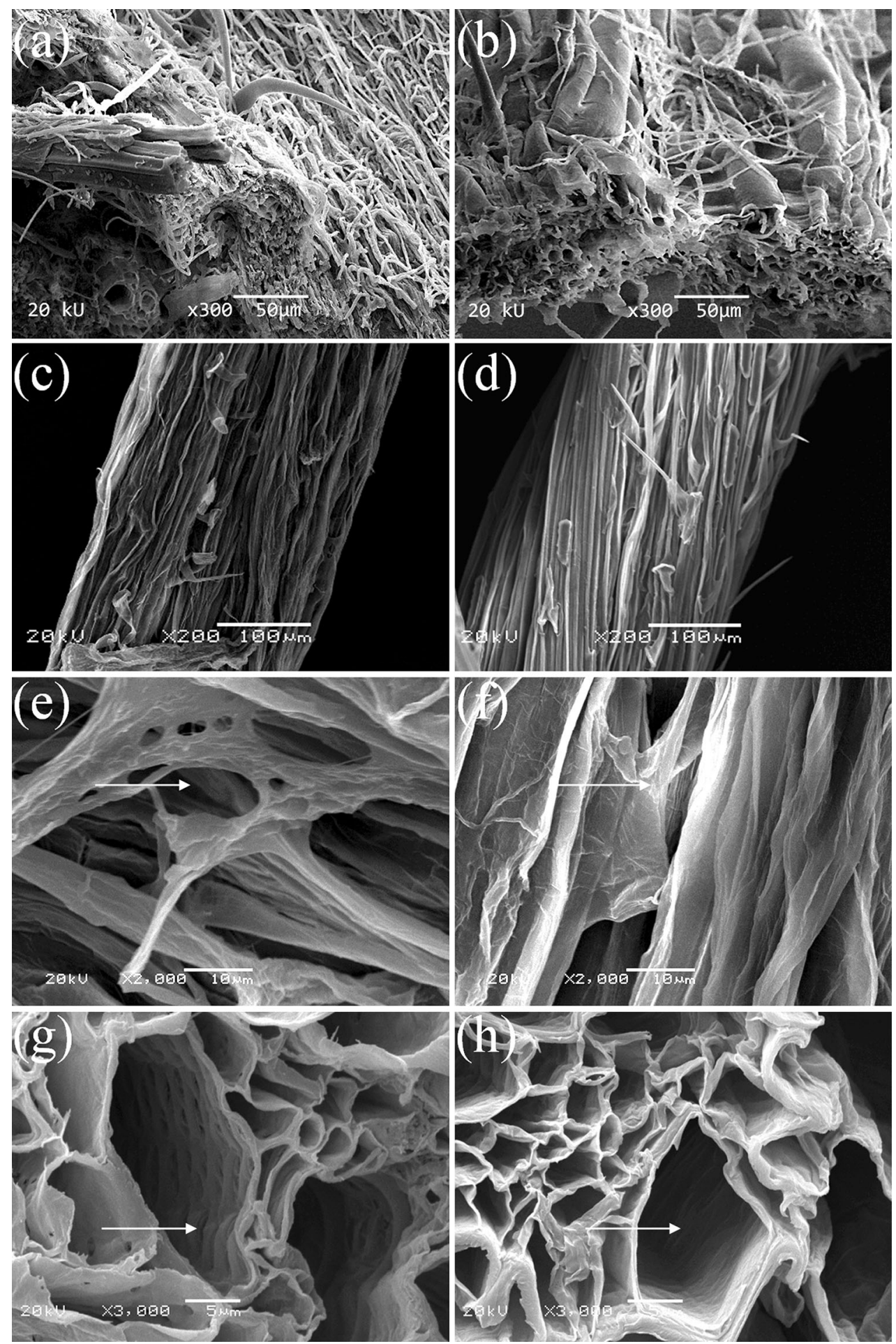

Fig. 1 SEM analysis of Hewo plants that were unhardened (a) and hardened (b), and infected with the fungal pathogen $M$. nivale as well as the structure of cellulose extracted from unhardened $(\mathbf{c}, \mathbf{e}, \mathbf{g})$ and

permeability for fungal-originated enzymes digesting the plant cell wall during an infection $[2,21]$. This effect is in agreement with the linear decrease in cell wall hardened (d, f, h) leaf fragments, which were not infected. Images show representative examples of samples selected from 20 biological repeats

permeability along with a prolongation of the hardening period (from 14 to 98 days) observed earlier for Hewo, but not for Magnat plants [2]. 


\section{Effect of cold treatment on cell wall composition}

Although, we present here that the effectiveness of fungal colonisation of the host tissue could be directly related to the structure and organisation of cellulose fibres, the reinforcement of the cell wall with lignin is known to be one of the most important factors determining resistance to a pathogen infection. Therefore, cell wall material was separated into three fractions related to: cellulose, lignin, and hemicelluloses together with other components (Table 1).

The extracted cellulose (Table 1) did not differ between Hewo and Magnat samples, as drastically as it was expected in order to explain the great structural variation in their cell wall structure (Fig. 1g, h). The cellulose amount in the hardened Hewo tissues was higher only c.a. $3 \%$ in comparison with other samples. Nevertheless, the degree of polymerisation determined with the viscometry technique showed much higher values for the cellulose isolated from hardened Hewo (Table 1). There was no significant difference in the degree of polymerisation within other samples.

The enrichment of Hewo cell walls in the lignin was also found, as the content of extracted lignin fraction was three times higher in comparison with Magnat. Cell wall fortification with lignin ensures higher mechanical stability of the tissue $[2,22]$ and can limit access to the host nutrients for fungal hyphae.

The changes in the cellulose and lignin contents were directly related to the diversity in other cell wall components, i.e. hardened (resistant) Hewo tissue had almost two times lower content of hemicelluloses than other samples. In unhardened plants, the higher hemicellulose content resulted in a weakening of their cell walls (Fig. 1). Hemicellulose have many branches and the degree of polymerisation between 100 and 200 [23]; therefore, its abundance leads to lower compaction of the cell wall.

\section{Stability of cellulose}

Differences in the cellulose content were too small to explain more solid structure of the resistant tissue (Fig. 1, Fig. 2). In this context, we performed a thermal analysis to confirm physicochemical properties influencing the cellulose stability. The amount of cellulose in all experiments was the same; therefore, differences during TG, DSC and QMS analysis were dependent on the genetic origin of samples and cold treatment.
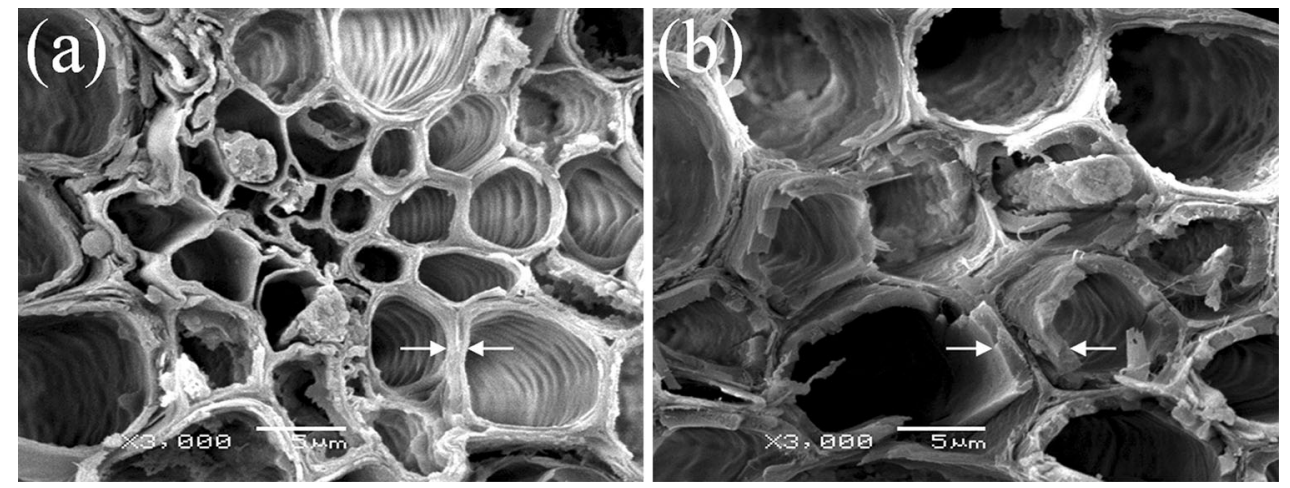

Fig. 2 SEM analysis of cold-induced changes in cellulose isolated from hardened leaves of Magnat (a) and Hewo (b) cultivars. Images show representative examples of samples selected from 20 biological repeats

Table 1 Cell wall fractions extracted from Hewo (H4, H20) and Magnat (M4, M20) plants that were hardened (H4, M4) and unhardened (H20, M20)

\begin{tabular}{llrrr}
\hline & Cellulose/\% & Cellulose DP & Lignin/\% & Hemicellulose and others/\% \\
\hline H4 & $36.96 \pm 0.98^{\mathrm{a}}$ & $1660 \pm 172^{\mathrm{a}}$ & $37.07 \pm 0.25^{\mathrm{a}}$ & $25.97 \pm 4.99^{\mathrm{c}}$ \\
H20 & $34.21 \pm 1.24^{\mathrm{b}}$ & $832 \pm 314^{\mathrm{b}}$ & $22.50 \pm 0.32^{\mathrm{b}}$ & $43.29 \pm 3.2^{\mathrm{b}}$ \\
M4 & $33.39 \pm 2.0^{\mathrm{b}}$ & $752 \pm 306^{\mathrm{c}}$ & $10.20 \pm 0.87^{\mathrm{c}}$ & $56.41 \pm 1.3^{\mathrm{a}}$ \\
M20 & $33.43 \pm 0.2^{\mathrm{b}}$ & $683 \pm 421^{\mathrm{c}}$ & $7.02 \pm 0.98^{\mathrm{c}}$ & $59.55 \pm 5.52^{\mathrm{a}}$ \\
\hline
\end{tabular}

Data are expressed as an amount of individual component (\% of DW of isolated cell wall). The average polymerisation degree of the cellulose (DP) was estimated viscometrically. A means are presented with the standard errors $(n=10)$ and different letters indicating the significant difference according to the Dunkan test $(P=0.05)$ 
Thermogravimetric analysis (TG) showed that initial stage of decomposition took place in a range of $50-300{ }^{\circ} \mathrm{C}$ and was related to a slow mass decrease: $2 \%$ for reference (Sigma), and 10-15.2\% for the triticale samples (Table 2). The major thermal degradation occurred within $300-365{ }^{\circ} \mathrm{C}$ (Fig. 3a), and 57.3-67.2\% of the mass loss was associated with this step (Table 2). Finally, the third stage began at about $365{ }^{\circ} \mathrm{C}$ and finished at $550{ }^{\circ} \mathrm{C}$ (Fig. 3a). The corresponding mass lost was $20 \%$ for reference and 10.6-12.9\% for triticale samples (Table 2). Over whole cellulose decomposition process, the remaining mass lowered in order: the hardened Hewo, unhardened Hewo, hardened Magnat and unhardened Magnat (Fig. 3a, Table 2). The same order was achieved, when susceptibility to pathogen infection and increase in cell wall digestion were distinguished (Figs. 1, 2) [2].

Complementary information was obtained from the DSC scans. A small endothermic peak at $90{ }^{\circ} \mathrm{C}$ was observed for the reference cellulose, whereas the DSC curve of the triticale cellulose exhibited two, wide peaks in the range of $50-150{ }^{\circ} \mathrm{C}$ and $150-300{ }^{\circ} \mathrm{C}$ (Fig. 3b). The peaks at $50-150^{\circ} \mathrm{C}$ had similar DSC maximum values $\left(-0.012 \mathrm{~mW} \mathrm{mg}^{-1}\right)$ for all of the triticale plants. However, the highest peak area was calculated for the hardened Hewo $\left(-15.2 \mathrm{~J} \mathrm{~g}^{-1}\right.$ ) (Table 3) indicating the requirement of high energy flow to perform processes and more difficult decomposition at this stage. Higher peak area resulted mainly from a longer shoulder of DSC peak at the higher temperatures side (Fig. 3b); the endset temperature was $158^{\circ} \mathrm{C}$ for $\mathrm{H} 4$ cellulose and $118.0-134.5^{\circ} \mathrm{C}$ for other samples (Table 3).

The initial mass loss at $50-150{ }^{\circ} \mathrm{C}$ and accompanying endothermic effects are attributed to the evaporation of moisture from the cellulose fibres $(\mathrm{m} / \mathrm{z} 18$ detected by QMS). Lower mass loss (Table 1) and wider endothermic DSC peak shifted to higher temperature (Fig. 3b, Fig. 4) indicate that cellulose from hardened Hewo had restricted abilities to water sorption and/or water molecules are bounded stronger within the polymer chains.

Differences were also detected for the second endothermic peaks with a maximum at around $229^{\circ} \mathrm{C}$ (Fig. 3b). The enhanced peak area $\left(-21.1 \mathrm{~J} \mathrm{~g}^{-1}\right)$ was determined for hardened Hewo, as a consequence of the higher temperature of endset (Table 3). Values for other samples were similar. Sample heating over $200{ }^{\circ} \mathrm{C}$ releases the water of crystallisation (anhydration) and the water from bonds breaking during cellulose decomposition into glucose monomers [24-27]. The analysis of gaseous products showed only minor changes in $\mathrm{CO}(\mathrm{m} / \mathrm{z}, 28)$ and $\mathrm{CO}_{2}(\mathrm{~m} / \mathrm{z}, 44)$; therefore, breaking of the internal glucose bonds did not occurred in the temperature range of $225-300{ }^{\circ} \mathrm{C}$. The lower TIC and lower intensity of $\mathrm{m} / \mathrm{z} 18$

Table 2 Remaining mass $(\%)$ and mass losses $(\Delta \mathrm{T}, \%)$ studied by thermogravimetry at selected temperatures during decomposition of cellulose extracted from Hewo (H4, H20) and Magnat (M4, M20) plants that were hardened (H4, M4) and unhardened (H20, M20). REF, reference cellulose

\begin{tabular}{lllllllll}
\hline$T /{ }^{\circ} \mathrm{C}$ & 150 & 300 & 365 & 550 & $\Delta T_{50-150}$ & $\Delta T_{150-300}$ & $\Delta T_{300-365}$ & $\Delta T_{365-550}$ \\
\hline REF & 99.5 & 98.0 & 30.8 & 10.8 & 0.5 & 1.5 & 67.2 & 20.0 \\
H4 & 99.3 & 90.0 & 29.8 & 19.2 & 0.7 & 12.3 & 60.2 & 10.6 \\
H20 & 99.1 & 87.1 & 29.8 & 17.0 & 0.9 & 12.7 & 57.3 & 59.4 \\
M4 & 98.5 & 85.8 & 26.4 & 13.5 & 1.5 & 11.7 & 61.1 & 12.8 \\
M20 & 96.5 & 84.8 & 23.7 & 11.3 & 3.5 & 12.4 \\
\hline
\end{tabular}

(a)

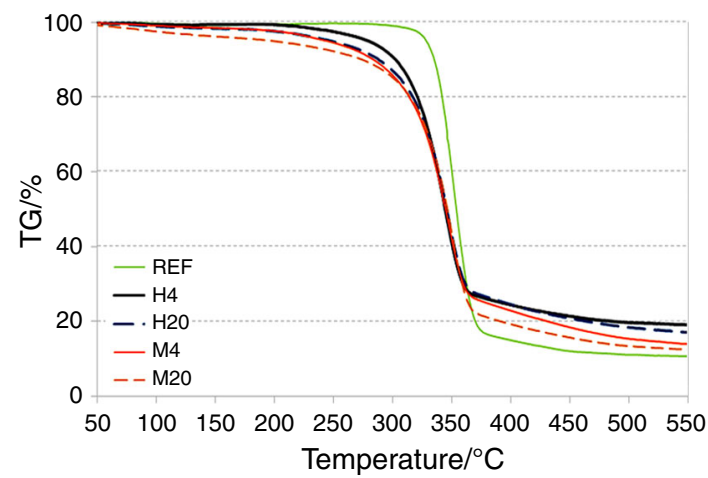

(b)

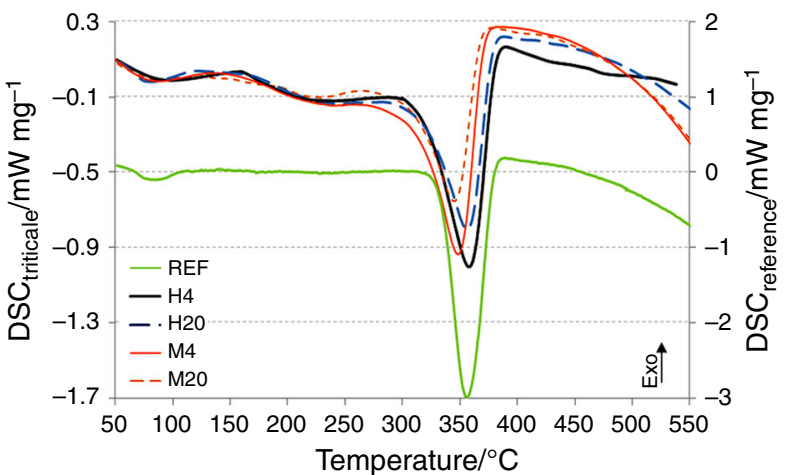

Fig. 3 Thermal decomposition of cellulose studied by thermogravimetry (a) and differential scanning calorimetry (b) for Hewo (H4, H20) and Magnat (M4, M20) plants that were hardened (H4, M4) or unhardened (H20, M20). REF, reference cellulose 
Table 3 Thermal effects studied by differential scanning calorimetry during decomposition of cellulose extracted from Hewo (H4, H20) and Magnat (M4, M20) plants that were hardened (H4, M4) and unhardened (H20, M20). REF, reference cellulose

\begin{tabular}{|c|c|c|c|c|c|c|c|c|c|c|c|c|}
\hline & \multicolumn{4}{|c|}{ I peak $\left(50-150{ }^{\circ} \mathrm{C}\right)$} & \multicolumn{4}{|c|}{ II peak $\left(150-300{ }^{\circ} \mathrm{C}\right)$} & \multicolumn{4}{|c|}{ III peak $\left(300-365^{\circ} \mathrm{C}\right)$} \\
\hline & $\begin{array}{l}T_{\max } / \\
{ }^{\circ} \mathrm{C}\end{array}$ & $\begin{array}{l}T_{\text {end }} / \\
{ }^{\circ} \mathrm{C}\end{array}$ & $\begin{array}{l}\mathrm{DSC}_{\max } / \mathrm{mW} \\
\mathrm{mg}^{-1}\end{array}$ & $\begin{array}{l}\text { Area / } \\
\mathrm{J} \mathrm{g}^{-1}\end{array}$ & $\begin{array}{l}T_{\max } / \\
{ }^{\circ} \mathrm{C}\end{array}$ & $\begin{array}{l}T_{\text {end }} / \\
{ }^{\circ} \mathrm{C}\end{array}$ & $\begin{array}{l}\mathrm{DSC}_{\text {max }} / \mathrm{mW} \\
\mathrm{mg}^{-1}\end{array}$ & $\begin{array}{l}\text { Area / } \\
\mathrm{J} \mathrm{g}^{-1}\end{array}$ & $\begin{array}{l}T_{\max } / \\
{ }^{\circ} \mathrm{C}\end{array}$ & $\begin{array}{l}T_{\text {end }} / \\
{ }^{\circ} \mathrm{C}\end{array}$ & $\begin{array}{l}\mathrm{DSC}_{\max } / \mathrm{mW} \\
\mathrm{mg}^{-1}\end{array}$ & $\begin{array}{l}\text { Area / } \\
\mathrm{J} \mathrm{g}^{-1}\end{array}$ \\
\hline REF & 88.7 & 106.8 & -0.111 & -10.9 & - & - & - & - & 355.8 & 389.8 & -2.989 & -449.7 \\
\hline $\mathrm{H} 4$ & 97.2 & 158.0 & -0.012 & -15.2 & 229.0 & 299.1 & -0.112 & -21.1 & 357.7 & 388.3 & -1.005 & -201.0 \\
\hline $\mathrm{H} 20$ & 89.0 & 134.5 & -0.012 & -13.6 & 229.0 & 289.0 & -0.131 & -18.7 & 356.3 & 389.7 & -0.805 & -176.2 \\
\hline M4 & 95.7 & 118.0 & -0.012 & -13.5 & 229.0 & 263.8 & -0.148 & -19.5 & 348.3 & 383.8 & -0.934 & -156.7 \\
\hline M20 & 88.9 & 124.2 & -0.012 & -10.3 & 223.0 & 265.4 & -0.101 & -17.9 & 345.5 & 378.9 & -0.655 & -127.6 \\
\hline
\end{tabular}

The temperature of decomposition maximum rate $\left(\mathrm{T}_{\max }\right)$, the final decomposition temperature $\left(\mathrm{T}_{\text {end }}\right)$, the DSC value of decomposition maximum rate $\left(\mathrm{DSC}_{\max }\right)$ and peak area are presented for each decomposition step (peak I, II, III)

$\left(\mathrm{H}_{2} \mathrm{O}\right)$ indicate again, the highest thermal stability of hardened Hewo cellulose at $150-300{ }^{\circ} \mathrm{C}$. It has been reported that the thermal stability of cellulose increases along with an increase in its molecular weight [26]. Therefore, we can concluded that cell wall of hardened Hewo consists tightly compacted aggregates of long cellulose chains (aggregated bundles of molecules), stabilized through the formation of intermolecular hydrogen bonding and hydrophobic interactions between the sugar rings. Such molecular structure was also confirmed by the higher value of the degree of polymerisation. In contrast, cellulose isolated from unhardened tissues was abundant in molecular water, and its structure was more amorphous. The gradual temperature increase from $180{ }^{\circ} \mathrm{C}$ to approximately $300{ }^{\circ} \mathrm{C}$ can induce thermal decomposition in such type of the cell wall, since degradation occurs first at the weak and exposed sites of the fibrils. Therefore, random chain scission leads easily to the formation of oligomers or monomers $[24,28]$.

Further increase in temperature led to main thermal effects at $320-360{ }^{\circ} \mathrm{C}$ (Fig. 3b). Although the peak of the reference cellulose was bigger $\left(\mathrm{DSC}_{\max }\right.$ value at $-3.0 \mathrm{~mW} \mathrm{mg}{ }^{-1}$ ), but shape and maximum of the peak were similar as for the triticale cellulose. The analysis of the triticale cellulose allowed identifying a divergence in the thermal effects that were depended on genotype and cold treatment. Hardened Hewo and hardened Magnat showed lower values of the DSC peak maximum (Fig. 3, Table 3), when compared to the unhardened samples. Furthermore, the peak maximum of unhardened and hardened Hewo was slightly shifted to higher temperatures (Fig. 3b, Table 3). The peak areas were in the range of -127.6 to $-201.0 \mathrm{~J} \mathrm{~g}^{-1}$, with the highest value corresponding to hardened Hewo cellulose (Table 3). The lowest amounts of total gaseous products (TIC) and products defined by $m / z=18,28,44,60,16,30,42,12$, and 68 were recorded for cellulose samples isolated from hardened
Hewo at $300-400{ }^{\circ} \mathrm{C}$. Moreover, all of the peaks were shifted to higher temperatures (Fig. 4), and associated with the higher remaining mass (TG, Table 1), and improved thermal effects (DSC, Fig. 2b). Therefore, we concluded that reduced release of oligomers and monomers at 180-300 ${ }^{\circ} \mathrm{C}$ was accompanied by their slower degradation into gaseous products at $300-400{ }^{\circ} \mathrm{C}$. It is known that main step of cellulose degradation into gases (at $300-400{ }^{\circ} \mathrm{C}$ ) usually takes place through two competing pathways: dehydration and depolymerisation [27, 29]. Dehydration leads directly to char and gaseous products (mainly $\mathrm{CO}$, $\mathrm{CO}_{2}$ and $\mathrm{H}_{2} \mathrm{O}$ ) resulting from cleavage of the $\mathrm{C}-\mathrm{O}$ bonds, whereas during depolymerisation, levoglucosan is formed, and then tar and volatiles. In our experiment, the highest QMID intensities were detected for $m / z 18\left(\mathrm{H}_{2} \mathrm{O}\right), \mathrm{m} / \mathrm{z} 28$ (corresponding to $\mathrm{CO}$ and to a lesser extent to the aliphatic molecules), and further $\mathrm{m} / z 44\left(\mathrm{CO}_{2}\right)$. The $\mathrm{m} / \mathrm{z}, 12$ related to carbon was also detected. Therefore, dehydration seems to be a more common pathway of degradation for triticale cellulose. Despite this, the depolymerisation process took place, as the gaseous products corresponding to levoglucosan $(\mathrm{m} / \mathrm{z} 60)$; levoglucosenone $(\mathrm{m} / \mathrm{z} 68)$, a representative of levoglucosan [29]; and organic components $\left(\mathrm{CH}_{4}, \mathrm{~m} / \mathrm{z}\right.$ 16; $\mathrm{C}_{2} \mathrm{H}_{6}, \mathrm{~m} / z, 30$; and $\mathrm{C}_{3} \mathrm{H}_{6}, \mathrm{~m} / z, 42$ ) were identified. However, the intensity and peak area of the depolymerisation-related ions were the lowest for hardened Hewo cellulose, indicating that depolymerisation process was inhibited in relation to dehydration. It indicates, that long and compact fibres of cellulose prevent its gradual depolymerisation, but after threshold temperature, dehydration can progress. We believe that this thermal behaviour can also be extrapolated to physiological features of cell wall. It can be correlated with the limited loosening of cell wall by fungal hyphae growing through cell interior, as the longer chains of cellulose and its improved degree of "crystallinity" determine cell wall mechanical resistance [13]. 

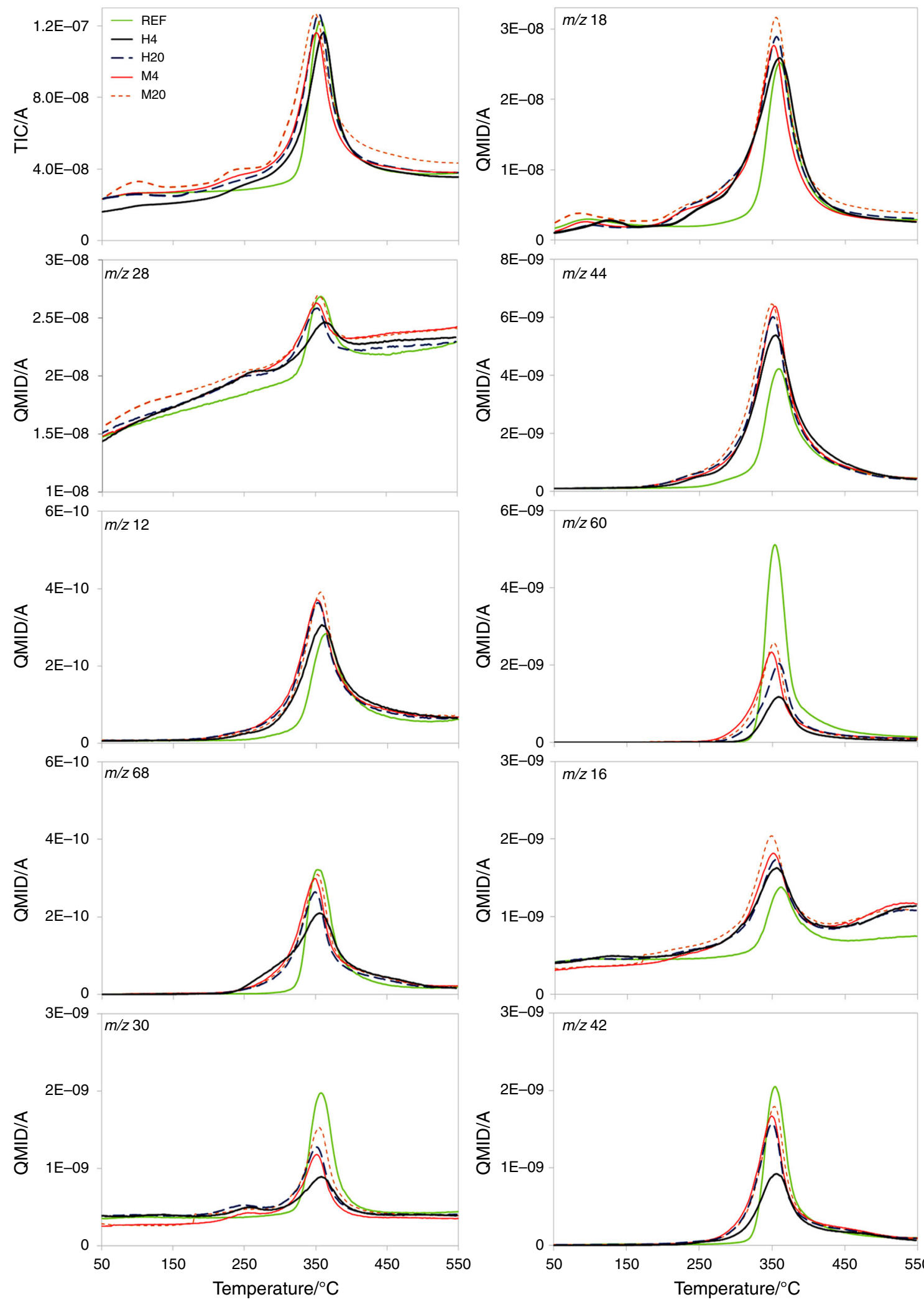

Fig. 4 Gaseous products released during cellulose thermal degradation studied by mass spectrometry. Cellulose was extracted from Hewo (H4, H20) and Magnat (M4, M20) plants that were hardened (H4, M4) or unhardened (H20, M20). REF, reference cellulose; TIC,

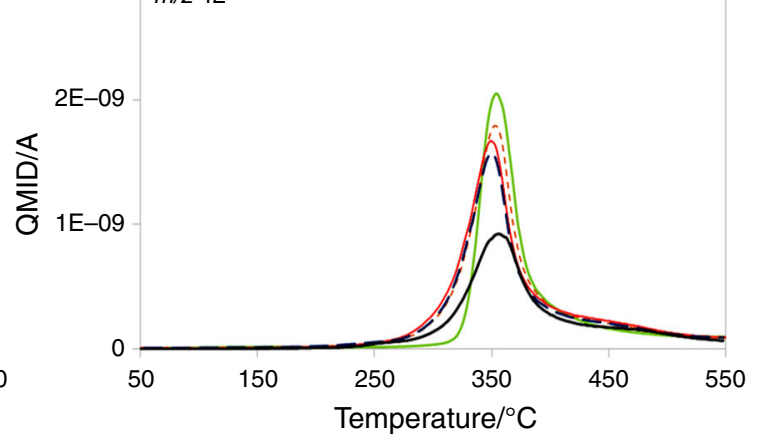

total ion current; QMID, signal from individual ion masses: water $(\mathrm{m} / \mathrm{z}, 18)$, carbon oxide $(\mathrm{m} / \mathrm{z}, 28)$, carbon dioxide $(\mathrm{m} / \mathrm{z}, 44)$, carbon $(\mathrm{m} / \mathrm{z}, 12)$, levoglucosan $(\mathrm{m} / \mathrm{z}, 60)$, levoglucosenone $(\mathrm{m} / \mathrm{z}, 68)$, methane $(\mathrm{m} / \mathrm{z}, 16)$, ethane $(\mathrm{m} / \mathrm{z}, 30)$, propene $(\mathrm{m} / \mathrm{z}, 42)$ 


\section{Stability of lignin}

Since lignin significantly contributes to mechanical properties of the cell wall (Table 1), thermal stability of this component was studied with TG/DSC/QMS. A multi-step degradation of lignin was observed during TG analysis in a temperature range from 50 to $500{ }^{\circ} \mathrm{C}$. The first small decomposition step was recorded at $50-150{ }^{\circ} \mathrm{C}$. The mass remaining after this step was the highest for $\mathrm{H} 4(96.3 \%)$ and much lower for other samples (92.2-94.6\%) (Table 4). The differences progressed extensively during whole decomposition process, and the TG changes at $550{ }^{\circ} \mathrm{C}$ varied over $37 \%$ between $\mathrm{H} 4$ and unhardened samples (H20 and M20, Fig. 5). This effect was clearly dependent on genotype and cold treatment, and the mass remaining lowered in the same order as the sensitivity to pathogen increased, i.e. hardened Hewo, unhardened Hewo, hardened Magnat, and then unhardened Magnat.

DSC analysis of the lignin reference has shown altered thermal behaviour; therefore it was not studied in details (Fig. 5b). The maximum point of the first triticale peak was observed at $85.8{ }^{\circ} \mathrm{C}$ and $102.4^{\circ} \mathrm{C}$ for $\mathrm{H} 4$ and $\mathrm{M} 4$, respectively (Fig. 5b, Table 5), and the peak was flattened for $\mathrm{H} 4$. $\mathrm{H} 20$ and M20 samples had peaks with maximum at about $140{ }^{\circ} \mathrm{C}$ (Fig. 5b). $T_{\max }$ of the second endothermic peak was at about $241{ }^{\circ} \mathrm{C}$ for both hardened samples (H4, M4), whereas the maximum for unhardened samples was shifted to higher temperatures, i.e. $242.3{ }^{\circ} \mathrm{C}$ and $247.3{ }^{\circ} \mathrm{C}$, for M20 and $\mathrm{H} 20$, respectively. The peaks of hardened samples were wider than those for unhardened ones, as longer shoulders on the low-temperature side were recorded (Fig. 5b, Table 5). Higher $\mathrm{DSC}_{\max }$ value and a smaller integrated peak area were also found for $\mathrm{H} 4$ in comparison with $\mathrm{H} 20$. Although, the high mass loss was observed at $300-450{ }^{\circ} \mathrm{C}$ (TG, Fig. 5a, Table 4), DSC analysis did not shown significant thermal effects at this decomposition step (Fig. 5b, Table 5).

The variation in TG and DSC effects was determined; therefore, the altered amount of volatiles was expected during the degradation of different samples. The shape of all TIC and QMID peaks strongly suggests that lignin isolated from various samples had different primary- and secondary structures. Indeed, the chemical and physical properties of lignin vary within type of tissues and cells and are strongly dependent on environmental conditions and growth season [27, 30-33]. The lowest TIC values and peaks' area during the whole thermal process were observed for H4 (Fig. 6), which explained the higher mass remaining after decomposition (Fig. 5a, Table 4). Higher TIC values were shown for the M4 sample. The peak maximum of the first decomposition step was shifted to lower temperature for both of the hardened samples, whereas the maximum of the third step was recorded at higher temperatures, when compared to the unhardened samples (Fig. 6). Therefore, the decomposition process of H4 and M4 occurred in a much wider temperature range, particularly for $\mathrm{H} 4$. Water desorption $(\mathrm{m} / \mathrm{z}, 18)$ explained the first and second TIC peak. The other gaseous products evolved during the second decomposition step with a decreasing ion intensity as follows: carbon oxide $(\mathrm{m} / \mathrm{z} 28)$, methanethiol $(\mathrm{m} / \mathrm{z} 48)$, carbon dioxide $(\mathrm{m} / \mathrm{z}, 44)$, methane $(\mathrm{m} / \mathrm{z}, 16)$, carbon $(\mathrm{m} / \mathrm{z}, 12)$, acetone $(\mathrm{m} / \mathrm{z}, 58)$, and propanamine/isopropylamine $(\mathrm{m} / \mathrm{z} 59)$. Additionally, during second decomposition step, propene $(\mathrm{m} / \mathrm{z}, 42)$, pyrrole $(\mathrm{m} / \mathrm{z} 67)$, phenol $(\mathrm{m} / z$ 94), dialkylpyrroles $(\mathrm{m} / \mathrm{z}$ 95) and furfuryl alcohol $(\mathrm{m} / \mathrm{z}$ 98) were detected for the unhardened Magnat samples. Such gaseous products were presented only during third step for other samples.

Lignins are formed by the oxidative polymerisation of three different types of hydroxycinnamyl alcohols (monolignols), which differ in the degree of aromatic ring methoxylation, i.e. (1) para-coumaryl alcohol, no methoxyl group; (2) coniferyl alcohol, one methoxyl group in position 3; and (3) sinapyl alcohol, two methoxyl groups in positions 3 and 5 . These three monolignols form $\mathrm{H}$-units (hydroxyphenyl), G-units (guaiacyl) and S-units (syringyl), respectively [34]. The lowest decomposition rate for lignin that was isolated from hardened Hewo leaves (TG i TIC and QMID) can be related to the limited presence of syringyl units in the lignin macromolecules. Syringyl and

Table 4 Remaining mass $(\%)$ and mass losses $(\Delta \mathrm{T}, \%)$ studied by thermogravimetry at selected temperatures during decomposition of lignin extracted from Hewo (H4, H20) and Magnat (M4, M20) plants that were hardened (H4, M4) and unhardened (H20, M20). REF, reference cellulose

\begin{tabular}{lllllcccc}
\hline$T /{ }^{\circ} \mathrm{C}$ & 150 & 180 & 300 & 550 & $\Delta T_{50-180}$ & $\Delta T_{180-300}$ & $\Delta T_{300-450}$ & $\Delta T_{450-550}$ \\
\hline REF & 94.7 & 94.2 & 86.2 & 61.8 & 5.8 & 8.0 & 20.4 & 4.0 \\
H4 & 96.3 & 94.8 & 81.3 & 57.2 & 5.2 & 13.5 & 5.3 \\
H20 & 94.6 & 92.1 & 64.2 & 19.3 & 7.9 & 27.9 & 37.6 & 7.3 \\
M4 & 92.2 & 88.7 & 63.6 & 35.8 & 11.3 & 25.1 & 20.0 & 7.8 \\
M20 & 92.7 & 89.7 & 61.2 & 20.0 & 10.3 & 28.5 & 34.7 & 6.5 \\
\hline
\end{tabular}


(a)

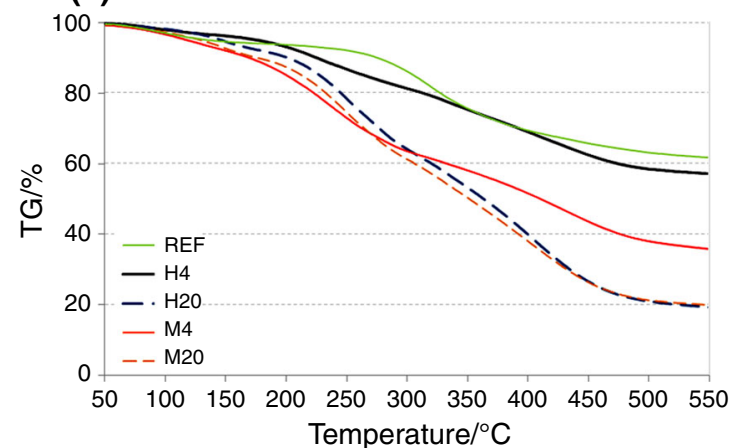

(b)

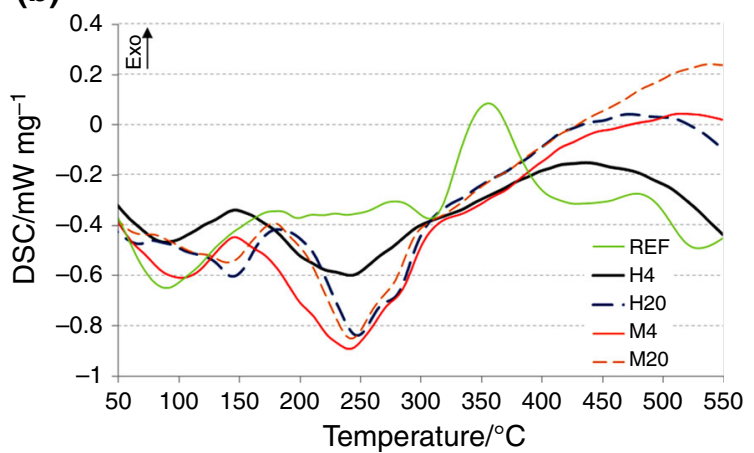

Fig. 5 Thermal decomposition of lignin studied by thermogravimetry (a) and differential scanning calorimetry (b) for Hewo (H4, H20) and Magnat (M4, M20) plants that were hardened (H4, M4) or unhardened (H20, M20). REF, reference lignin

Table 5 Thermal effects studied by differential scanning calorimetry during decomposition of lignin extracted from Hewo (H4, H20) and Magnat (M4, M20) plants that were hardened (H4, M4) and unhardened (H20, M20). REF, reference cellulose

\begin{tabular}{|c|c|c|c|c|c|c|c|c|c|c|c|c|}
\hline & \multicolumn{4}{|c|}{ I peak $\left(50-180{ }^{\circ} \mathrm{C}\right)$} & \multicolumn{4}{|c|}{ II peak $\left(180-300{ }^{\circ} \mathrm{C}\right)$} & \multicolumn{4}{|c|}{ III peak $\left(300-450{ }^{\circ} \mathrm{C}\right)$} \\
\hline & $\begin{array}{l}T_{\max } / \\
{ }^{\circ} \mathrm{C}\end{array}$ & $\begin{array}{l}T_{\text {end }} / \\
{ }^{\circ} \mathrm{C}\end{array}$ & $\begin{array}{l}\mathrm{DSC}_{\text {max }} / \mathrm{mW} \\
\mathrm{mg}^{-1}\end{array}$ & $\begin{array}{l}\text { Area/ } \\
\mathrm{J} \mathrm{g}^{-1}\end{array}$ & $\begin{array}{l}T_{\max } / \\
{ }^{\circ} \mathrm{C}\end{array}$ & $\begin{array}{l}T_{\text {end }} / \\
{ }^{\circ} \mathrm{C}\end{array}$ & $\begin{array}{l}\mathrm{DSC}_{\max } / \mathrm{mW} \\
\mathrm{mg}^{-1}\end{array}$ & $\begin{array}{l}\text { Area/ } \\
\mathrm{J} \mathrm{g}^{-1}\end{array}$ & $\begin{array}{l}T_{\max } / \\
{ }^{\circ} \mathrm{C}\end{array}$ & $\begin{array}{l}T_{\text {end }} / \\
{ }^{\circ} \mathrm{C}\end{array}$ & $\begin{array}{l}\mathrm{DSC}_{\max } / \mathrm{mW} \\
\mathrm{mg}^{-1}\end{array}$ & $\begin{array}{l}\text { Area/ } \\
\mathrm{J} \mathrm{g}^{-1}\end{array}$ \\
\hline REF & 89.5 & 175.1 & -0.648 & -102.8 & 198.1 & 279.9 & -0.370 & -13.4 & 355.3 & 405.4 & 0.085 & 123.3 \\
\hline $\mathrm{H} 4$ & 85.8 & 146.5 & -0.465 & -41.3 & 241.5 & 303.0 & -0.598 & -115.7 & 360.6 & 417.6 & -0.270 & 0.838 \\
\hline $\mathrm{H} 20$ & 144.2 & 186.3 & -0.603 & -57.4 & 247.3 & 310.3 & -0.839 & -163.3 & 363.6 & 417.4 & -0.203 & -1.135 \\
\hline M4 & 102.4 & 146.2 & -0.610 & -62.3 & 241.0 & 311.3 & -0.894 & -239.6 & 364.7 & 417.2 & -0.273 & -9.059 \\
\hline M20 & 139.5 & 179.6 & -0.548 & -62.4 & 242.3 & 299.2 & -0.851 & -158.7 & 358.2 & 416.5 & -0.219 & -1.071 \\
\hline
\end{tabular}

The temperature of decomposition maximum rate $\left(\mathrm{T}_{\max }\right)$, the final decomposition temperature $\left(\mathrm{T}_{\text {end }}\right)$, the DSC value of decomposition maximum rate $\left(\mathrm{DSC}_{\max }\right)$ and peak area are presented for each decomposition step (peak I, II, III)

guaiacyl units are built into the lignin mainly by alkyl-aryl ether linkages $\beta-0-4$ bonds. However, it is a well known fact that $\beta-0-4$ linkages between guaiacol units are more difficult to split, than those between syringyl. Therefore, guaiacol-type phenols easily undergo ionic condensation under pyrolytic conditions, mainly via radical coupling reactions on the aromatic ring in ortho or meta position to the phenolic $\mathrm{OH}$ groups. Such condensation products remain in the tar fraction or in the solid coal residue. The consequence is the lower yield of monomeric phenolics and higher yield of coal residues in the case of $G$ lignins $[34,35]$. This mechanism can explain the highest yields of carbonised residues and higher remaining mass at the end of decomposition of the H4 lignin. In the same way, the rupture of thermolabile ester and ether bonds in syringyl units can explain higher degradability of the lignin isolated from unhardened samples. Indeed, the higher amount of small organic volatiles (QMID), and consequently lower tendency for condensation (lower remaining mass detected by TG) were recorded mainly for unhardened Magnat. Moreover, the most organic products, i.e. unsaturated hydrocarbons (propene), carbonyls (acetone), and aromatics (pyrrole and phenol) were released from the unhardened samples already at $245{ }^{\circ} \mathrm{C}$, whereas from hardened Hewo lignin at the third stage of the decomposition process $\left(300-550{ }^{\circ} \mathrm{C}\right)$.

The contamination with cellulose can take place during lignin extraction, and similar with lignin during cellulose extraction. However, thermal analysis confirmed the purity of both isolated components. The reference cellulose and plant cellulose had similar TG courses, with the main decomposition step at $240-362{ }^{\circ} \mathrm{C}$. The cellulose degradation at $290-350{ }^{\circ} \mathrm{C}$ was earlier stated in the theoretical stoichiometric studies and confirmed experimentally for the intact cell wall $[24,36]$. Further, the DSC peaks were clear-cut and the degradation of other components, e.g. phenolics, hemicelluloses or lignin, did not overlap them,

Fig. 6 Gaseous products released during lignin thermal degradation studied by mass spectrometry. Lignin was extracted from Hewo (H4, H20) and Magnat (M4, M20) plants that were hardened (H4, M4) or unhardened (H20, M20). REF, reference lignin; TIC, total ion current; QMID, signal from individual ion masses: water $(\mathrm{m} / \mathrm{z}, 18)$, carbon oxide $(\mathrm{m} / \mathrm{z} 28)$, methanethiol $(\mathrm{m} / \mathrm{z} 48)$, carbon dioxide $(\mathrm{m} / \mathrm{z} 44)$, methane $(\mathrm{m} / \mathrm{z} 16)$, carbon $(\mathrm{m} / \mathrm{z} 12)$, acetone $(\mathrm{m} / \mathrm{z} 58)$, propanamine/ isopropylamine $(\mathrm{m} / \mathrm{z} 59)$, propene $(\mathrm{m} / \mathrm{z} 42)$, pyrrole $(\mathrm{m} / \mathrm{z} 67)$, phenol $(\mathrm{m} / \mathrm{z}, 94)$, and dialkylpyrroles $(\mathrm{m} / \mathrm{z} 95)$, furfuryl alcohol $(\mathrm{m} / \mathrm{z} 98)$, levoglucosan $(\mathrm{m} / \mathrm{z}, 60)$, levoglucosenone $(\mathrm{m} / \mathrm{z}, 68)$ 
(a)
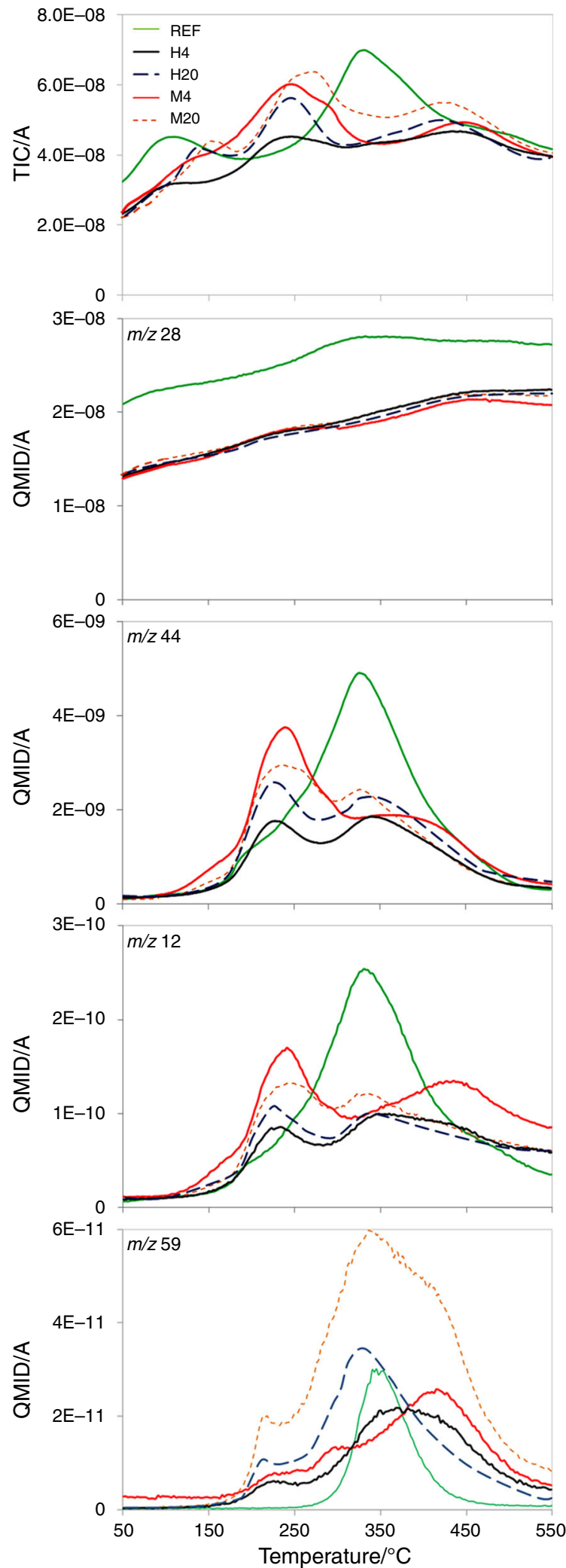
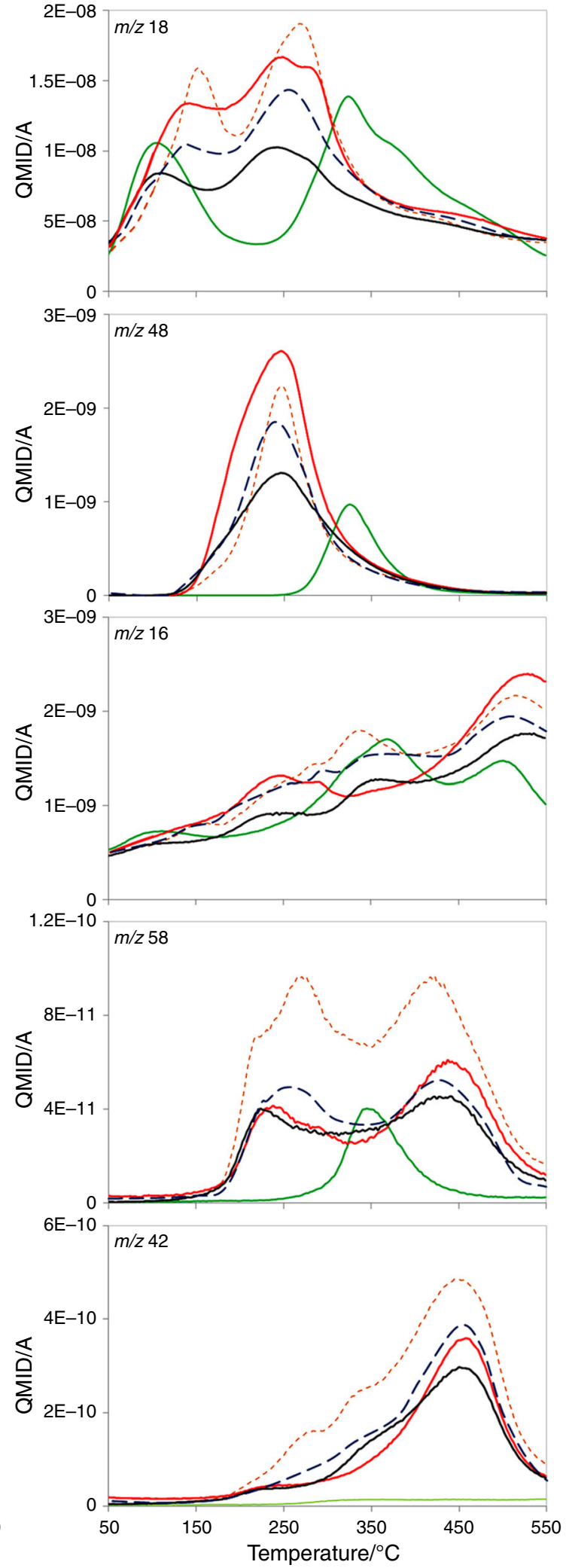


\section{(b)}

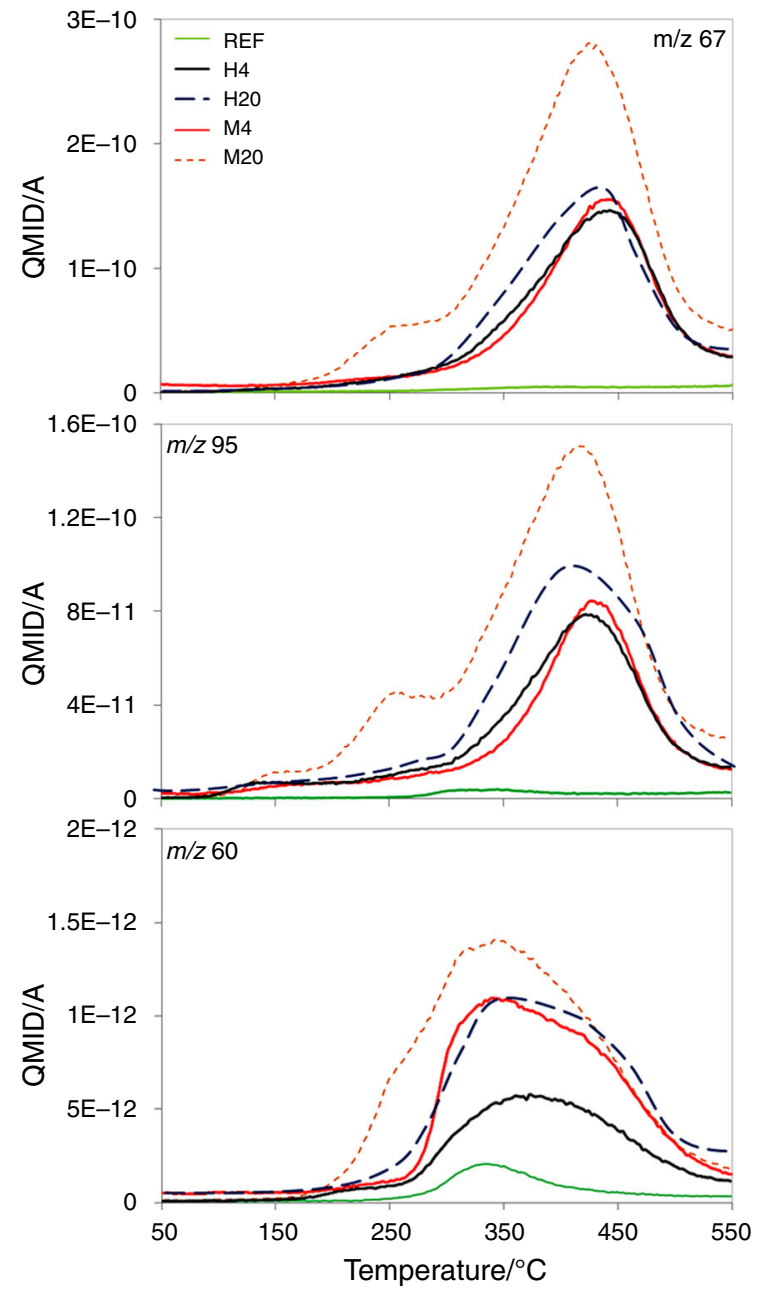

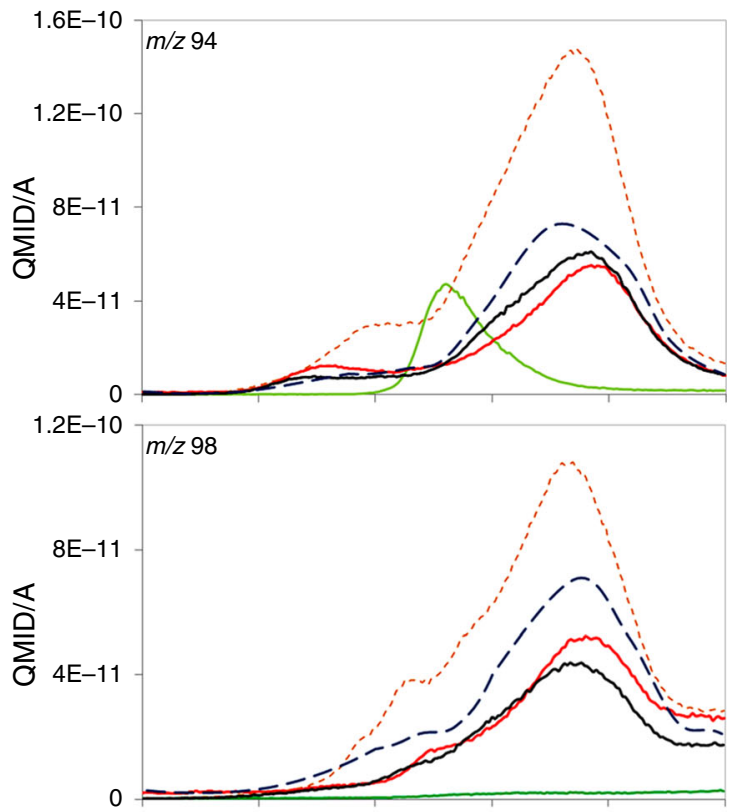

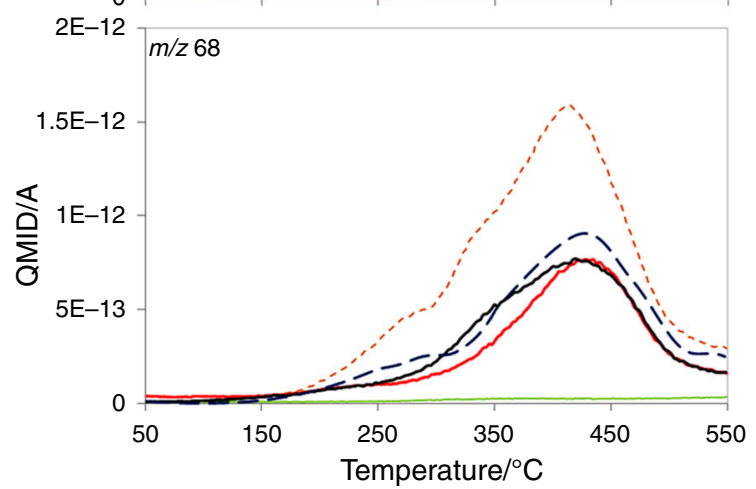

Fig. 6 continued

as for the intact cell wall [2]. Finally, the lignin-originated products (e.g. furfuryl alcohol, $m / z$ 98) were present in the cellulose samples in very small amount, and similarly the ion intensity for the cellulose-originated products (e.g. levoglucosan, $\mathrm{m} / \mathrm{z}$ 60; and levoglucosenone, $\mathrm{m} / \mathrm{z}$ 68) was below 2E-12 (QMS analysis). Thus, all alterations in the thermal decomposition of both cell wall components were related to structural and chemical differences of the studied samples.

\section{Conclusions}

Taken together, structural analyses and TG/DSC/QMS indicate the compact structure of the cellulose extracted from triticale cultivar that is resistant to pathogens after cold treatment. Moreover, higher stability of lignin, and its altered chemical composition can also play an important role in cold-induced resistance. We cannot consider interactions of various components of the cell wall, as the separation process can modify the structure of cellulose and lignin. However, based on the general agreement that the cell wall is formed via the successive deposition of cellulose, followed by lignification process, in this way, cellulose provides a key structural pattern for assembly of lignin. Lignification is a tightly regulated and dynamic process subject to post-modulation in response to abiotic and biotic stresses [30, 37]. Therefore, the decrease in the porosity of the cellulose network together with the greater stability of lignin formed in cold conditions can reduce the cell wall permeability for fungus-originated enzymes and increase its mechanical strength that prevents hyphae invasion.

Acknowledgements $\mathrm{MSH}$ and $\mathrm{MH}$ were supported by the project PBS1/A8/0/2012 (WOODTECH) financed by the National Centre for Research and Development. 
Open Access This article is distributed under the terms of the Creative Commons Attribution 4.0 International License (http://crea tivecommons.org/licenses/by/4.0/), which permits unrestricted use, distribution, and reproduction in any medium, provided you give appropriate credit to the original author(s) and the source, provide a link to the Creative Commons license, and indicate if changes were made.

\section{References}

1. Cantu D, Vicente AR, Labavitch JM, Bennett AB, Powell ALT. Strangers in the matrix: plant cell walls and pathogen susceptibility. Trends in Plant Sci. 2008;13:610-7.

2. Szechyńska-Hebda M, Hebda M, Mierzwiński D, Kuczyńska P, Mirek M, Wędzony M, van Lammeren A, Karpiński S. Effect of cold-induced changes in physical and chemical leaf properties on the resistance of winter triticale (xTriticosecale) to the fungal pathogen Microdochium nivale. Plant Pathol. 2013;62:867-78.

3. Wojtasik W, Kulma A, Kostyn K, Szopa J. The changes in pectin metabolism in flax infected with Fusarium. Plant Physiol Biochem. 2011;49:862-72.

4. Hückelhoven R. Cell wall-associated mechanisms of disease resistance and susceptibility. Annu Rev Phytopathol. 2007;2007(45): 101-27.

5. Lynne H, Thomas V, Forsyth T, Šturcová A, Kennedy CJ, May RP, Altaner CM, Apperley DC, Wess TJ, Jarvis MC. Structure of cellulose microfibrils in primary cell walls from collenchyma. Plant Physiol. 2013;161:465-76.

6. Wegst UG, Bai H, Saiz E, Tomsia AP, Ritchie RO. Bioinspired structural materials. Nat Mater. 2015;14:23-36.

7. Szechyńska-Hebda M, Wąsek I, Gołębiowska-Pikania G, Dubas E, Żur I, Wędzony M. Photosynthesis-dependent physiological and genetic crosstalk between cold acclimation and cold-induced resistance to fungal pathogens in triticale (Triticosecale Wittm.). J Plant Physiol. 2015;177:30-43.

8. Ślesak I, Szechyńska-Hebda M, Fedak H, Sidoruk N, DąbrowskaBronk J, Witoń D, Rusaczonek A, Antczak A, Drożdżek M, Karpińska B, Karpiński S. PHYTOALEXIN DEFICIENT4 affects reactive oxygen species metabolism, cell wall and wood properties in hybrid aspen (Populus tremula L. x tremuloides). Plant, Cell Environ. 2015;38:1275-84.

9. Szechyńska-Hebda M, Kruk J, Górecka M, Karpińska B, Karpiński S. Evidence for light wavelength-specific photoelectrophysiological signaling and memory of excess light episodes in Arabidopsis. Plant Cell. 2010;22:2201-18.

10. Szechyńska-Hebda M, Wedzony M, Tyrka M, Gołębiowska M, Chrupek M, Czyczyło-Mysza I, Dubas E, Żur I, Golemiec E. Identifying QTLs for cold-induced resistance to Microdochium nivale in winter triticale. Plant Genetic Resources: Characterization and Utilization. 2011;9:296-9.

11. Yang X, Ye CY, Bisaria A, Tuskan GA, Kalluri UC. Identification of candidate genes in Arabidopsis and Populus cell wall biosynthesis using text-mining, co-expression network analysis and comparative genomics. Plant Sci. 2011;181:675-87.

12. Guerriero G, Giorno F, Ciccotti AM, Schmidt S, Baric S. A gene expression analysis of cell wall biosynthetic genes in Malus $\mathrm{x}$ domestica infected by 'Candidatus Phytoplasma mali'. Tree Physiol. 2012;32:1365-77.

13. Burton RA, Gidley MJ, Fincher GB. Heterogeneity in the chemistry, structure and function of plant cell walls. Nature Chem. Biol. 2010;6:724-36.

14. Verbelen JP, Vissenberg K, Kerstens SLJ. Cell expansion in the epidermis: microtubules, cellulose orientation and wall loosening enzymes. J Plant Physiol. 2001;158:537-43.
15. Kerstens S, Decraemer WF, Verbelen JP. Cell walls at the plant surface behave mechanically like fiber-reinforced composite materials. Plant Physiol. 2001;127:381-5.

16. Srivastava S, Gupta RK, Arha M, Vishwakarma RK, Rawal SK, Kishor PBK, Khan BM. Expression analysis of cinnamoyl-CoA reductase $(C C R)$ gene in developing seedlings of Leucaena leucocephala: a pulp yielding tree species. Plant Physiol Biochem. 2011;49:138-45.

17. ISO 5351/1 (1981): Cellulose in dilute solutions - Determination of limiting viscosity number. Part 1: Method in cupri-ethylenediamine (CED) solution.

18. Hebda M, Gądek S, Skałoń M, Kazior J. Effect of mechanical alloying and annealing on the sintering behaviour of AstaloyCrL powders with $\mathrm{SiC}$ and carbon addition. J Therm Anal Calorim. 2013;113:395-403.

19. Hebda M, Gądek S, Kazior J. Influence of the mechanical alloying process on the sintering behaviour of Astaloy CrM powder mixture with silicon carbide addition. Arch Metall Mater. 2012;57:733-43.

20. Nakajima T, Abe J. Environmental factors affecting expression of resistance to pink snow mold caused by Microdochium nivale in winter wheat. Can J Bot. 1996;74:1783-8.

21. Barna B, Fodor J, Harrach BD, Pogány M, Király Z. The Janus face of reactive oxygen species in resistance and susceptibility of plants to necrotrophic and biotrophic pathogens. Plant Physiol Biochem. 2012;59:37-43.

22. Schmidt M, Schwartzberg AM, Perera PN, Weber-Bargioni A, Carroll A, Sarkar P, Bosneaga E, Urban JJ, Song J, Balakshin MY, Capanema EA, Auer M, Adams PD, Chiang VL, Schuck PJ. Label-free in situ imaging of lignification in the cell wall of low lignin transgenic Populus trichocarpa. Planta. 2009;230: 589-97.

23. Sun RC, Tomkinson J. Characterization of hemicelluloses isolated with tetraacetylethylenediamine activated peroxide from ultrasound irradiated and alkali pre-treated wheat straw. Eur Polymer J. 2003;39:751-9.

24. Brebu M, Vasile C. Thermal degradation of lignin-a review. Cellulose chemistry and technology. Cellulose Chem. Technol. 2010;44:353-63.

25. Hnilička F, Hniličková H, Hejnák V. Use of combustion methods for calorimetry in the applied physiology of plants. J Therm Anal Calorim. 2015;120:411-7.

26. Ibbett R, Gaddipati S, Davies S, Hill S, Tucker G. The mechanisms of hydrothermal deconstruction of lignocellulose: new insights from thermal-analytical and complementary studies. Biores. Tech. 2011;102:9272-8.

27. Liodakis S, Bakirtzis D, Lois E. TG and autoignition studies on forest fuels. J Therm Anal Calorim. 2002;69:519-28.

28. Santos LB, Striebeck MV, Crespi MS, Ribeiro CA, De Julio M. Characterization of biochar of pine pellet. J Therm Anal Calorim. 2015;122(1):21-32.

29. Qu H, Wu W, Wu H, Xie J, Xu J. Study on the effects of flame retardants on the thermal decomposition of wood by TG-MS. J Therm Anal Calorim. 2011;103:935-42.

30. Boudet AM. Lignins and lignification: selected issues. Plant Physiol Biochem. 2000;38:81-96.

31. Marga F, Gallo A, Hasenstein KH. Cell wall components affect mechanical properties: studies with thistle flowers. Plant Physiol Biochem. 2003;41:792-7.

32. Hatakeyama H, Tsujimoto Y, Zarubin MJ, Krutov SM, Hatakeyama $\mathrm{T}$. Thermal decomposition and glass transition of industrial hydrolysis lignin. J Therm Anal Calorim. 2010;101: 289-95.

33. Christiernin M. Structure of lignins in developing xylem of Norway spruce. Plant Physiol Biochem. 2006;44:700-6. 
34. Day A, Neutelings G, Nolin F, Grec S, Habrant A, Cronier D, Maher B, Rolando C, David H, Chabbert B, Hawkins S. Caffeoyl coenzyme A O-methyltransferase down-regulation is associated with modifications in lignin and cell-wall architecture in flax secondary xylem. Plant Physiol Biochem. 2009;47:9-19.

35. Faix O, Jakab E, Till F, Székely T. Study on low mass thermal degradation products of milled wood lignins by thermogravimetry-mass-spectrometry. Wood Sci Technol. 1988;22:323-34.
36. Hebda M, Laska M, Szechyńska-Hebda M. Application of a device used for observation of controlled thermal processes in a furnace. J. Therm. Anal. Calorim. 2013;114:1099-109.

37. Szechyńska-Hebda M, Czarnocka W, Hebda M, Karpiński S. PAD4, LSD1 and EDS1 regulate drought tolerance, plant biomass production, and cell wall properties. Plant Cell Rep. 2016;35:527-39. 